\title{
Oral verrucous carcinoma: From multifactorial etiology to diverse treatment regimens (Review)
}

\author{
QIAN PENG, YUEHONG WANG, HONGZHI QUAN, YIPING LI and ZHANGUI TANG \\ Xiangya Stomatological Hospital, Central South University, Changsha, Hunan 410008, P.R. China
}

Received February 6, 2016; Accepted March 28, 2016

DOI: 10.3892/ijo.2016.3501

\begin{abstract}
Oral verrucous carcinoma (OVC) is a verrucous variant of oral squamous cell carcinoma (OSCC), which accounts for $2-12 \%$ of all oral carcinomas with a 5 -year survival rate of only approximately $50 \%$. Enormous effort has been dedicated to this cancer, and the past decades have witnessed significant advances in relevant diagnostic and therapeutic approaches. Currently, there exist three challenges from primary sub-fields of research and clinical practice of the cancer, namely multifactorial etiology, complex molecular mechanism, and deficient treatment. This study reviews the existing literature on the cancer, encompassing its etiology, clinical manifestations and pathology, molecular mechanism, diagnosis and differential diagnosis, and treatment. For improved treatment of OVC, multifactorial etiology analysis, incorporation of effective biomarkers for mechanism illustration, and integration of multidisciplinary modalities are expounded, in an attempt to resolve the challenges and to provide a useful guide for future research in the field.
\end{abstract}

\section{Contents}

1. Introduction

2. Etiology

3. Clinical manifestations and pathology

4. Molecular mechanisms

5. Diagnosis and differential diagnosis

6. Treatment

7. Discussion

8. Conclusions

Correspondence to: Professor Zhangui Tang, Xiangya Stomatological Hospital, Central South University, 72 Xiangya Road, Changsha, Hunan 410008, P.R. China

E-mail: zhgtang@csu.edu.cn

Key words: oral cancer, oral verrucous carcinoma, oral squamous cell carcinoma, multifactorial etiology, biomarkers, differential diagnosis, surgery

\section{Introduction}

Head and neck malignant carcinoma is the world's fifth most common cancer with incidence exceeding half a million annually $(1,2)$. Oral squamous cell carcinoma (OSCC) represents $95 \%$ of head and neck malignant carcinoma (3). As a low-grade and well-differentiated verrucous variant of OSCC, oral verrucous carcinoma (OVC) accounts for $2-12 \%$ of all oral carcinomas with a 5-year survival rate of only approximately $50 \%$, and is receiving increasing attention (4).

OVC is a malignant tumor characterized by slow exophytic growth, usually presenting cauliflower-like and pebbly mamillated warty lesions (5). It shows a typical 'pushing border' (light and electron) microscopic feature with a local invasive pattern and rare regional and distant metastases (6). The history of OVC can be traced back to as early as 1948 when it was first described by Lauren V. Ackermann (also referred to as 'Ackermann's tumor' or 'verrucous carcinoma of Ackermann') (7). Its pathology was not studied independently until mid-1980s (8). Although ensuing research on diagnosis and treatment of OVC was largely triggered at the beginning of this century (9), the research progress is still far from satisfactory. For instance, the differentiation of OVC from OSCC is important regarding their different molecular mechanisms and prognoses. However, it is currently difficult to differentiate them by simply observing clinical and pathological features because OVC has similar biological behavior to OSCC, including tendency to local invasion, insidious lymph node metastasis and occurrence of malignant lesions (10). These similarities usually cause clinical misdiagnosis and mistreatment (11). Undoubtedly, it is critical to seek reliable molecular markers of OVC to resolve such challenges.

Over the past several decades, there have been numerous studies concerning precise diagnosis and effective treatment of OVC (12-14). The authors' research group has been investigating this type of cancer since 1992 (14). As a timely and detailed review about OVC is still lacking at present, this paper aims to deliver an overview of OVC with emphasis on recent research developments. It covers almost all subfields of OVC, including its etiology, clinical manifestations and pathology, molecular mechanism, diagnosis and differential diagnosis, and treatments, followed by a detailed discussion on main challenges confronted in the field and promising measures for resolving them. This review is expected to offer a useful guide for research development and clinical practice of OVC. 


\section{Etiology}

OVC has complex etiology which depends on a variety of factors $(15,16)$. There exist strong associations between OVC and alcohol consumption, smoking, areca nut chewing and oral microbiota (17-21). These factors may act individually or synergistically in oral carcinogenesis. OVC also has a relationship with undesirable prosthesis, earlier injuries and scars, and chronic inflammation. Moreover, it may occur as a result of deterioration of premalignant lesions, including oral verrucous leukoplakia, oral lichen planus, oral submucous fibrosis (OSF), odontogenic keratocyst (22).

Alcohol and smoking related carcinogens are two main wellestablished risk factors for oral cancers including OVC (18). Excessive alcohol consumption can increase incidence of OVC because alcohol may act as a solvent that promotes movement of carcinogens via oral cellular membranes, as the consumption has the capability to change intracellular metabolism of the epithelial cells, causing impairment of cellular function (e.g., reduced mitochondrial function and enhanced DNA alkylation) in the initial phase of oral carcinogenesis $(23,24)$. Similar to alcohol consumption, smoking is another potential factor that may induce OVC (19). In fact, there exist over 300 carcinogens, i.e., aromatic hydrocarbon benz-pyrene and the tobacco specific nitrosamines (TSNs), in tobacco smoke or its water-soluble components that will leach into saliva. These carcinogens interfere with DNA replication by generating DNA adducts, primarily 06 methyl Guanine, damaging replicating cells of the immune response $(25,26)$.

Areca nut extracts contain various carcinogens, such as $\mathrm{N}$-nitroso amines. These carcinogens cause DNA singlestrand breaks and mutations, facilitating tumor formation and growth. Furthermore, arecoline in areca nut extracts has genetic toxicity and teratogenicity on a variety of cells, playing an important role in oral carcinogenesis (20).

Oral microbiota may present a non-ignorable role in oral carcinogenesis through their impacts on local metabolism of alcohol and smoking-related carcinogens. It was found that five bacterial phyla, including Firmicutes, Proteobacteria, Bacteroidetes, Actinobacteria, and Fusobacteria, are associated with oral cancer (21). They activate alcohol and smoking related carcinogens locally. Oral bacteria can convert ethanol to acetaldehyde, an in vitro and in vivo genotoxin, exposing the oral and gastrointestinal tract directly to carcinogenic acetaldehyde after alcohol use (27). The bacteria may function in enhanced activation of carcinogenic nitrosamines from tobacco smoking because in vitro common oral microbes activate nitrosodiethylamine (NDEA, a tobacco smoke nitrosamine) to its carcinogenic (IARC, Group 2A) adduct-forming hydroxylated product (28).

Among other potential causes of OVC, of interest is the controversial and inconclusive pathogenic role of human papillomavirus (HPV) (29-31). Some researchers considered that HPV was a possible pathogeny of OVC (32-35). NobleTopham et al reported the detection of HPV DNA in 12 (48\%) of 25 OVC patients. Specifically, HPV 6b/11 DNA, HPV 16 DNA, HPV 18 DNA, and HPV 16 DNA plus HPV 18 DNA were detected in one (4\%), one (4\%), nine (36\%), and one $(4 \%)$ cases, respectively. The detection of HPV 18 DNA in $40 \%$ of OVCs reveals an association between HPV and OVC although the potential etiologic and prognostic significance of HPV in OVC deserves further exploration (34). On the contrary, other scholars argued that the role of HPV might be occasional as there was no verified correlation between OVC and HPV in their work (36-38). For instance, de Spíndula-Filho et al examined the role of HPV in cellular proliferation in OVC based on quantitative analyses of 39 OSCCs, 8 OVCs and 9 normal mucosa samples. No correlation between HPV and OVC was established in this study because all samples tested were negative for HPV (36). Evidently, there is conflicting research regarding the role of HPV. Further studies on determination of appropriate sample size and use of highly sensitive molecular biology techniques (e.g., polymerase chain reaction) are expected to produce new information in order to gain further understanding on the topic.

\section{Clinical manifestations and pathology}

Clinical manifestations. OVC often occurs in buccal mucosa, tongue, lip, gingiva, alveolar ridge and mouth floor (39), exhibiting a predilection for elderly males, especially those over the age of sixty $(40,41)$. Its predominant clinical manifestations are exophytic mass and papillary appearance. Due to its slow growth which contributes to long medical history (up to several years) and to the local aggression that leads to rare regional or distant metastasis, OVC has a relatively good prognosis (42). According to clinical manifestations and prognosis, Tang et al first divided OVC into three types: exogenic type, cystoid type, and infiltrative type $(14,43)$. The exogenic type of OVC is characterized by exophytic growth, cauliflower-like warty lesion and slow tumor growth. However, the other two types of OVC grow rapidly, forming bean dreg-like white dry keratosis, accompanying poor prognosis compared to the exogenic type of OVC.

\section{Pathology}

Pathological features in optical microscopy. OVC epithelial cells are well differentiated with weak cell atypia. In optical microscopy, the squamous epithelium of OVC shows highly proliferative, papillary appearance and excess aceratosis. The highly proliferative epithelial pegs show swelling and blunt ends in the shape of liquid droplets. All epithelial pegs are infiltrated to the connective tissue in the same depth, forming pushing borders (44). Many lymphocytes and plasma cells are also infiltrated into the connective tissue in which cancer cells may degenerate or become necrosis or be swallowed by phagocytic cells, resulting in carcinoma cell destruction. Between squamous epithelium and connective tissue, the majority of components of epithelial basement membrane (BM) of OVC remains integrated.

Pathological features in electron microscopy. The pathological features of OVC can be reflected by its stereology in the electron microscopy. The stereology of OVC observed under a transmission electron microscope usually shows thick and intact basement membrane of the cancer with obviously thicker substrate than the normal cells in local areas. With increased inflammatory cells (e.g., lymphocytes and plasma cells), the basement membrane is disrupted in some cases. The ultrastructural pathological features of the exogenic type of OVC in the electron microscopy are well differentiated 
epithelial cells with keratocyst, large and regular nucleus with obvious nucleolus, no pseudopodia on the membrane and no cytoplasmic vacuolation. However, for the cystoid type and infiltrative type of OVC, they have poorly-differentiated epithelial cell with obvious heteromorphism, large, irregular and lobulated nucleus, clear pseudopodia on the membrane and obvious cytoplasmic vacuolation (43).

\section{Molecular mechanisms}

The development of OVC is a multistep process involving the accumulation of multiple genetic alterations modulated by genetic predisposition and environmental influences such as tobacco use, alcohol consumption, microbial infections, and chronic inflammation. All of these factors can result in a wide range of genetic alterations and epigenetic modifications that can be detected in a range of molecular studies. Exploration of molecular mechanism is important for reducing the morbidity and mortality and for improving long-term survival rate of OVC It mainly focuses on seeking definitive and effective molecular biomarkers which are widely used to identify the evolution of dysplasia lesions to cancer. Up to now, a large number of studies have been carried out to reveal the molecular mechanism of OVC from perspectives of genetics and epigenetics $(45,46)$.

Genetics. The molecular mechanism of OVC is closely associated with its genetics. Genetic alterations are involved in polymorphism, point mutation, deletion, and other alterations. Previous investigation mainly focused on gene profiling $(47,48)$.

As a special type of OSCC, OVC has its own specific clinical manifestations and pathological features. Further understanding of the molecular mechanisms of OVC requires gene expression differentiation between OVC and OSCC. In fact, many genes express differentially between OVC and OSCC, and some of them are closely related to cancer progression of OVC. To identify key genes that regulate and control the biological behavior of OVC, Wang et al differentiated gene expression profiles between OVC and OSCC (49). The cancer tissues and the matched normal oral mucosa tissues from 5 OVC patients and 6 OSCC patients were analyzed using the Affymetrix HG-U133 Plus 2.0. The function and biological pathways of gene were profiled with the Ingenuity Systems IPA software. It was found that 167 genes expressed differentially between OVC and OSCC. Among them, 108 genes were upregulation and 59 genes were downregulation. Compared with their matched normal mucosa tissues, 39 common genes were expressed differentially (22 upregulation, 17 downregulation) between OVC and OSCC. Some of these 39 genes were related to the networking functions including cellular movement, genetic disorder, inflammatory response and immune cell trafficking. Between OVC and OSCC, 8 of the 39 genes, namely ADAMTS12 (a disintegrin and metalloproteinase with thrombospondin motifs), COL4A1 ( $\alpha 1$ type IV collagen), COL4A2 ( $\alpha 2$ type IV collagen), INHBA (inhibin, $\beta A$ ), MMP1 (matrix metalloproteinase 1), SERPINE1 (serpin peptidase inhibitor, clade E, member 1), TGFBI (transforming growth factor, $\beta$-induced), and HLF (human lactoferrin), were expressed differentially and considered effective biomarkers in differentiating OVC and OSCC.
Epigenetics. The cellular and physiological trait variations of OVC may not involve changes in DNA sequence. Carcinogenesis is a multistep process modulated by a number of epigenetics modifications (50). Prior research devoted much effort to identification of molecular mechanism of OVC from epigenetics perspective according to number and percentages of molecules in each functional category, including tumor growth (cell cycle acceleration and proliferation), tumor suppression (antitumor defense and apoptosis), angiogenesis and tumor invasion and metastasis. The corresponding biomarkers for diagnosis of OVC are summarized in Table I.

Tumor growth (cell cycle acceleration and proliferation) markers. Cell cycle refers to eukaryotic cells with continued division from the end of mitotic cycle growing to the end of next mitotic cycle. Cancer cells often have an abnormal mitotic cycle. Cell proliferation, differentiation, senescence and apoptosis are closely related to the cell cycle regulatory machinery (51). The markers associated with the dysregulation of the cell cycle machinery usually indicate cancer progression. As shown in Table I, the most intensively investigated tumor growth markers for OVC diagnosis are cyclins including cyclin-B1 (36) and cyclin-D1 (52), proliferating cell nuclear antigen (PCNA) (53), Ki67 (54), $\alpha \mathrm{B}$-crystallin (55), S-phase kinase-interacting protein 2 (SKp2) (56), mutant p53 (57) and p63 (58). Most of these markers express in a decreasing order from OSCC through OVC to normal mucosal tissue. Note that the expression levels of some tumor growth markers, (e.g., Cyclin-D1 and PCNA in Table I) remain controversial in welldifferentiated OSCC and a part of OVC with strong tendency to local invasion.

Tumor suppressor markers (antitumor defense and apoptosis). During the cell cycle, cyclins control the progression of cancer cells by activating cyclin-dependent kinase (CDK). The progression of OVC may be restrained by a series of CDK inhibitors, e.g., INK4 (Inhibitor of CDK4, including p15, p16, p18 and p19) and Kip (Kinase inhibition protein, such as p21, p27, and p57) $(59,60)$. Other tumor suppression markers include proteins phosphatase and tensin homologue (PTEN) (61), quinone oxidoreductase 1 (NQO1), superoxide dismutase (SOD) (62), and inducible nitric oxide synthase (iNOS) (63). As presented in Table I, the majority of the markers have a declining expression order from oral premalignant lesions, such as dysplastic epithelium, OVH, OSF and oral epithelial dysplasia (OED), through OVC to OSCC. It is worth noting that the typical tumor suppressor protein, wild-type p53, is absent in Table I because its role as a marker for OVC is still unconfirmed.

Angiogenesis markers. Angiogenesis is crucial in the occurrence, development and prognosis of tumor. Angiogenesis markers may have the potential for diagnosis and prevention of carcinomas (64). The markers of angiogenesis may be used for the prognosis and treatment of OVC. As shown in Table I, the vascular endothelial growth factor (VEGF) family is thought to be one of the strongest angiogenesis simulators that induce blood vessel growth. It also induces formation of vascular cavity and increases vascular permeability. Hence, VEGF is regarded as a marker of metabolism and transformation of OVC (62). 
Table I. Potential markers for OVC (in previous studies).

\begin{tabular}{|c|c|c|c|c|c|}
\hline Classification & Marker & Function & $\begin{array}{l}\text { Expression in } \\
\text { OVC compared } \\
\text { to normal tissues } \\
\text { (NT) or OSCC }\end{array}$ & Effects & Refs. \\
\hline \multirow[t]{8}{*}{ Tumor growth } & Cyclin B1 & $\begin{array}{l}\text { Regulating cell cycle } \\
\text { (G2-M phase) }\end{array}$ & $\mathrm{OSCC}>\mathrm{OVC}>\mathrm{NT}$ & $\begin{array}{l}\text { Differentiation of OVC from OSCC } \\
\text { and prognosis of OVC }\end{array}$ & 36 \\
\hline & Cyclin-D1 & $\begin{array}{l}\text { Regulating cell } \\
\text { cycle (G1-S phase) }\end{array}$ & $\begin{array}{l}\text { Poorly-differentiated } \\
\text { OSCC>moderately- } \\
\text { differentiated } \\
\text { OSCC>OVC> well- } \\
\text { differentiated OSCC }\end{array}$ & $\begin{array}{l}\text { Histological grading of OSCC and } \\
\text { differentiation of OVC from OSCC }\end{array}$ & 52 \\
\hline & PCNA & $\begin{array}{l}\text { Regulating cell } \\
\text { cycle (late G1- } \\
\text { S phase) }\end{array}$ & $\begin{array}{l}\text { Well-differentiated } \\
\text { OSCC }>\mathrm{OVC}>\mathrm{OVH}>\mathrm{NT}\end{array}$ & Prognosis of OVC & 53 \\
\hline & Ki67 & $\begin{array}{l}\text { Regulating } \\
\text { cell cycle (G1-S-G2 } \\
\text { phase) }\end{array}$ & $\mathrm{OSCC}>\mathrm{OVC}$ & $\begin{array}{l}\text { Prognosis of OVC within which } \\
\text { OSCC arises }\end{array}$ & 54 \\
\hline & $\alpha \mathrm{B}$-crystallin & Anti-apoptosis & $\mathrm{OSCC}>\mathrm{OVC}>\mathrm{NT}$ & $\begin{array}{l}\text { Carcinogenesis by controlling } \\
\text { activation of caspase- } 3\end{array}$ & 55 \\
\hline & SKp2 & $\begin{array}{l}\text { Regulating cell } \\
\text { cycle (G1 phase) }\end{array}$ & OVC, OSCC $>\mathrm{NT}$ & Prognosis of OVC & 56 \\
\hline & Mutant p53 & $\begin{array}{l}\text { Contributing to } \\
\text { oncogenesis } \\
\text { instead of } \\
\text { suppressing tumor }\end{array}$ & $\mathrm{OSCC}>\mathrm{OVC}>\mathrm{NT}$ & $\begin{array}{l}\text { Differentiation of OVC from OSCC } \\
\text { and histological grading of OSCC } \\
\text { at invasive front regions }\end{array}$ & 57 \\
\hline & p63 & $\begin{array}{l}\text { Maintaining } \\
\text { epithelial cell } \\
\text { regeneration and } \\
\text { homeostasis }\end{array}$ & $\mathrm{OSCC}>\mathrm{OVC}$ & Diagnosis of OVC & 58 \\
\hline \multirow[t]{6}{*}{$\begin{array}{l}\text { Tumor } \\
\text { suppression }\end{array}$} & p16 & $\begin{array}{l}\text { Preventing cells } \\
\text { from going through } \\
\text { G1-S phase, } \\
\text { inhibiting DNA } \\
\text { synthesis and cell } \\
\text { proliferation }\end{array}$ & $\begin{array}{l}\text { OVC>OSCC; } \\
\text { OVC>dysplastic } \\
\text { epithelium }\end{array}$ & $\begin{array}{l}\text { Pathogenesis of OVC with } \\
\text { overexpression of } \mathrm{p} 16 \text { caused } \\
\text { by inactivation of } \mathrm{pRb}\end{array}$ & 59 \\
\hline & $\mathrm{p} 21$ & $\begin{array}{l}\text { Mediating growth } \\
\text { arrest (G1 and } \\
\mathrm{S} \text { phases) and } \\
\text { inhibiting DNA } \\
\text { synthesis }\end{array}$ & $\mathrm{OVH}>\mathrm{OVC}$ & Pathogenesis of OVC & 60 \\
\hline & $\mathrm{p} 27$ & $\begin{array}{l}\text { Stopping/reducing } \\
\text { the cell division } \\
\text { cycle ( } \mathrm{G} 1 \text { phase) }\end{array}$ & $\begin{array}{l}\text { Dysplastic } \\
\text { lesions }>\mathrm{OVC}>\mathrm{OSCC}\end{array}$ & Pathogenesis of OVC & 59 \\
\hline & PTEN & $\begin{array}{l}\text { Restraining cell } \\
\text { growth in the } \mathrm{G} 1 \\
\text { phase, apoptosis } \\
\text { and impeding cell } \\
\text { invasion and } \\
\text { metastasis }\end{array}$ & $\mathrm{NT}>\mathrm{OVC}, \mathrm{OSCC}$ & Diagnosis of OVC & 61 \\
\hline & $\begin{array}{l}\text { NQO1 and } \\
\text { SOD }\end{array}$ & $\begin{array}{l}\text { Antioxidation, } \\
\text { anti-aging, and } \\
\text { detoxification }\end{array}$ & $\mathrm{OVC}>\mathrm{OSCC}$ & $\begin{array}{l}\text { Differentiation of OVC } \\
\text { from OSCC }\end{array}$ & 62 \\
\hline & iNOS & $\begin{array}{l}\text { Overproduction of } \\
\text { iNOS suppressing } \\
\text { tumor growth and } \\
\text { inducing apoptosis }\end{array}$ & $\mathrm{OVH}=\mathrm{OSF}>\mathrm{OVC}$ & $\begin{array}{l}\text { (Pre)malignant carcinogenesis } \\
\text { and prognosis of OVC }\end{array}$ & 63 \\
\hline
\end{tabular}


Table I. Continued.

\begin{tabular}{|c|c|c|c|c|c|}
\hline Classification & Marker & Function & $\begin{array}{l}\text { Expression in } \\
\text { OVC compared } \\
\text { to normal tissues } \\
\text { (NT) or OSCC }\end{array}$ & Effects & Refs. \\
\hline Angiogenesis & VEGF & $\begin{array}{l}\text { Inducing blood } \\
\text { vessel growth and } \\
\text { formation of } \\
\text { vascular cavity }\end{array}$ & $\mathrm{OSCC}>\mathrm{OVC}$ & $\begin{array}{l}\text { Differentiation of OVC } \\
\text { from OSCC }\end{array}$ & 62 \\
\hline \multirow[t]{6}{*}{$\begin{array}{l}\text { Tumor invasion } \\
\text { and metastasis }\end{array}$} & \multirow[t]{3}{*}{ MMPs } & \multirow[t]{3}{*}{$\begin{array}{l}\text { Degrading } \\
\text { extracellular matrix } \\
\text { and basement } \\
\text { membrane }\end{array}$} & $\begin{array}{l}\text { Absence of MMP-7, } \\
-9 \text { and }-12 \text { in OVC } \\
\text { rather than OSCC }\end{array}$ & $\begin{array}{l}\text { Differentiation, diagnosis and } \\
\text { prognosis of OVC }\end{array}$ & 71 \\
\hline & & & $\begin{array}{l}\text { MMP-2, MMP-9: high- } \\
\text { grade OSCC }>\text { low-grade } \\
\text { OSCC }>\text { OVC }>\text { NT }\end{array}$ & $\begin{array}{l}\text { Differentiation of OVC and } \\
\text { OSCC and histological grading } \\
\text { of OSCC at invasive front regions }\end{array}$ & 57 \\
\hline & & & MMP-10: OSCC $>\mathrm{OVC}>\mathrm{NT}$ & $\begin{array}{l}\text { Differentiation of OVC and } \\
\text { OSCC at invasive front regions }\end{array}$ & 72 \\
\hline & $\begin{array}{l}\text { Basement } \\
\text { membrane } \\
(\mathrm{BM}) \\
\text { proteins }\end{array}$ & $\begin{array}{l}\text { A supporting pad } \\
\text { for epithelial cells, } \\
\text { connecting } \\
\text { epithelial tissues } \\
\text { and connective } \\
\text { tissues }\end{array}$ & $\begin{array}{l}\text { Laminin: OED }>\text { OVC }>O S C C \\
\text { collagen IV: OVC }>\text { OED; } \\
\text { discontinuities of laminin, } \\
\text { collagen IV and fibronectin: } \\
\text { OED }>\text { OVC }\end{array}$ & $\begin{array}{l}\text { Tumor invasion indicated by } \\
\text { BM loss. Differentiation of OVC } \\
\text { from OSCC and OED }\end{array}$ & 73 \\
\hline & Moesin & $\begin{array}{l}\text { Cross-linkers } \\
\text { affecting cell-cell } \\
\text { recognition and } \\
\text { signaling and } \\
\text { cell movement }\end{array}$ & $\begin{array}{l}\text { Well-differentiated } \\
\text { OSCC }>\text { OED }>\text { OVC }> \\
\text { moderately-differentiated } \\
\text { OSCC }>\text { poorly-differentiated } \\
\text { OSCC }\end{array}$ & $\begin{array}{l}\text { Differentiation of OVC from } \\
\text { OED and OSCC }\end{array}$ & 74 \\
\hline & $\begin{array}{l}\text { Laminin-332 } \\
\gamma_{2}\end{array}$ & $\begin{array}{l}\text { A component of } \\
\text { BM associated } \\
\text { with cell migration } \\
\text { and tumor invasion }\end{array}$ & $\begin{array}{l}\text { Well-differentiated } \\
\text { OSCC }>\text { OVC }\end{array}$ & $\begin{array}{l}\text { Differentiation of OVC from } \\
\text { well-differentiated OSCC }\end{array}$ & 75 \\
\hline
\end{tabular}

Tumor invasion and metastasis markers. Tumor cells break through the extracellular matrix and basement membrane, which is an important step during the process of tumor invasion and metastasis (65). Many matrix metalloproteinases (MMPs) play significant roles in this process, including MMP-1, $-2,-7,-9,-10,-12,-13,-14,-19$, and -26 (66-68). Moreover, basement membrane, composed of laminin, collagen IV and fibronectin (69), is a continuous, insoluble but flexible structure located between the basal surface of epithelium and connective tissue. As a selective barrier for molecules, basement membrane is closely related to cell differentiation, cell migration, and tumorigenesis (70). Table I shows different expression levels of tumor invasion and metastatic potential markers (71-75) for OVC.

\section{Diagnosis and differential diagnosis}

Diagnosis. The diagnosis of OVC includes two aspects: clinical and pathological diagnosis. In the clinical aspect, OVC usually has a characteristic exophytic mass, cauliflower-like warty lesion and slow growth. On the pathological examination, the most important and typical pathological features of OVC are infiltration of all rete pegs to the connective tissue in the same depth which forms pushing borders. These features can be used to diagnose some OVC cases with acceptable accuracy. However, for accurate diagnosis, multiple factors except for clinical and pathological features should be considered to eliminate the influence of other lesions on discrimination, such as OSCC within hybrid VC. First, as pathological diagnosis is subjective, different explanations may occur for the same phenomenon. Second, collection of remarkable characteristic CT and MRI images of OVC may substantially improve the diagnosis. Third, reliable genes and proteins may be sought as diagnostic markers for OVC. Lastly, the medical history and clinical manifestations can serve as good references for the diagnosis.

Differential diagnosis. Although much effort has been spent on differential diagnosis of OVC, gold diagnosis standards or specific diagnostic markers are still lacking. The main reasons are as follows: First, OVC is similar to many diseases in clinical and pathological aspects. Different OVC cases may 
show different biological behaviors. Second, for the same OVC, it may be diagnosed differently when pathological examination is performed on different sites. Third, hybrid verrucous carcinoma, composed of OVC and differently-differentiated OSCC, may exist. This type of carcinoma has more aggressive invasion nature with incidence rate up to $20 \%$ (76). Obviously, it is crucial to make a differential diagnosis between OVC and other similar diseases for improving treatment and prognosis.

OVC and oral verrucous hyperplasia (OVH). OVC and OVH are two distinctive oral verrucous lesions in the clinicopathology in spite of their similar morphologies in the clinical and histopathological aspects (77,78). From the clinical aspect, both of them have a thick, extensive, white plaque, or exophytic verrucous appearance. The most common sites for the two lesions are buccal mucosa, tongue and lip. However, to differentiate them effectively, some histopathological features may be used because OVC has the explicit 'pushing broader' feature with destructive extrapolation edges at the junction of lower connective tissues, whereas OVH does not show invasion of the hyperplastic epithelium into the lamina propria compared with adjacent normal mucosal epithelium. Further differentiation can also be achieved with the assistance of biomarkers. For instance, CD34, $\alpha$-smooth muscle actin and HuR protein have the capability to diagnose OVC and OVH $(79,80)$.

OVC and oral squamous papilloma (OSP). Oral squamous papilloma (OSP) shares similar morphology to OVC. OSP and OVC are often clinically present as exophytic, cauliflower and papillary forms. From the histopathological point of view, it is possible to differentiate OSP from OVC. For OVC, all rete pegs of the epithelium tend to project into the underlying connective tissue, at more or less the same level, forming 'pushing border.' OSP often presents as many long, thin and finger-like projections which extend above the mucosal surface. Each finger-like projection, which contains a central connective tissue, is lined by stratified squamous epithelium. The upper epithelial cells of OSP have pyknotic and crenated nuclei, which are often surrounded by edematous or optically clear zone, known as 'koilocytic' cell (81). The differentiation can also be achieved by using some proteins as markers. These proteins include the cytokeratins (CKs) family (e.g., CK $10,13,14$ and 16), whose expression relates to the biological behavior of both lesions (82).

OVC and OSCC. As aforementioned, OVC has a strong tendency to local invasion whereas metastasis is rarely seen (83). OVC has some pathological similarities to OSCC, especially for well-differentiated OSCC and OVC. Aiming at assessing and validating biomarkers for better understanding of the genesis and molecular mechanisms of OVC and OSCC, Pentenero et al (84) found OVC and OSCC could be differently characterized using chromosomal instability biomarkers. The difference in aggressiveness and prognosis of OVC and OSCC was reflected by DNA index characteristics. Some tumor genes and molecular markers including Cyclin-D1, laminin-332 $\gamma 2$, PCNA, moesin, MMP-2, MMP-9 can also be used for comparative evaluation of OVC and OSCC, especially for OVC and well-differentiated OSCC, guiding clinicians to make an accurate diagnosis $(52,53,57,74,75)$.
OVC and oral hybrid verrucous carcinoma. Oral hybrid verrucous carcinoma (VC) is a neoplasm composed of OVC and differently-differentiated OSCC (85). For example, welldifferentiated OSCC was identified within OVC and invaded the underlying connective tissue and bone (76). Unlike OVC, oral hybrid VC is staged and graded similar to OSCC. However, the proportion of conventional OVC component may vary and the prognosis of hybrid $\mathrm{VC}$ with high proportion of OVC may have better prognosis than OSCC. Due to high similarity in staging and grading, incision biopsy is extremely unreliable to diagnose and differentiate oral hybrid VC from OVC (86). For diagnosis of this hybrid tumor, it is necessary to examine an adequate biopsy sample extending to the underlying bone for examination of the periosteum and the mucosa-connective tissue interface.

\section{Treatment}

The general treatment principles of OVC are consistent with OSCC, but the treatment of OVC has its own characteristics. Since the first report of OVC there have been debates regarding the treatment of choice for this tumor. The treatment regimens mainly include surgery, chemotherapy, radiotherapy or combinations, cryotherapy, and shave excision. However, surgery for wide lesion area usually results in uncosmetic appearance and dysfunction. Chemotherapy or radiotherapy may have poor response and anaplastic transformation, and thus questionable effectiveness. Regarding these issues, unconventional treatment modalities have been put forward in recent years. They include photodynamic therapy and $\mathrm{CO}_{2}$ laser therapy. The details of these treatment regimens for $\mathrm{OVC}$ are summarized in Table II.

Surgery. Surgery has been considered the preferred treatment for OVC $(87,88)$. The aim of surgery is to eradicate the tumor without disabling function. For the exogenic type of OVC, surgical excision is the first-line method due to its controlled size, rare tumor recurrence, and good prognosis. However, for the hybrid type of OVC, the surgical excision should be progressive. The excision boundary needs careful estimation because the excision sizes for the hybrid type of OVC are usually much broader. Incomplete or excessive resection often accelerates tumor growth, leading to anaplastic transformation, poor function and difficult reconstruction. In this case, surgery (e.g., primary tumor resection and neck dissection) combined with radiotherapy and chemotherapy may be appropriate to minimize tumor recurrence and undesired prognosis (88-90). Table II shows the uses of surgery for OVC since mid-1980s, clearly demonstrating its effectiveness after treatment (91-94).

Radiotherapy. OVC was initially thought to be somewhat radioresistant in the oral cavity or the larynx (95). It was reported the local recurrence rate could reach as high as 57\% by following radiotherapy, resulting from the high incidence rate of multiple primary tumors. The anaplastic transformation may also occur in $>10 \%$ of OVC cases (96). In fact, the treatment policy mainly depends on the extension of the primary tumor and on the regional nodal involvement. The patients who undergo surgery are usually in Stage I or II, whereas radiotherapy (or combined with surgery) appears more suit- 
Table II. Treatment regimens for OVC (in previous studies).

\begin{tabular}{|c|c|c|c|c|c|}
\hline $\begin{array}{l}\text { Treatment } \\
\text { regimen }\end{array}$ & $\begin{array}{c}\text { Number of } \\
\text { patients/gender }\end{array}$ & Time/age & $\begin{array}{c}\text { Specific treatment } \\
\text { modalities and } \\
\text { additional information }\end{array}$ & $\begin{array}{l}\text { Results (recurrence rate, } \\
\text { RR; disease-free survival, } \\
\text { DFS; overall survival } \\
\text { rate, OSR) }\end{array}$ & Refs. \\
\hline Surgery & 101/M: 79, F: 22 & $\begin{array}{l}1990 \text { to } 2000 / 53.9 \\
\text { (average) }\end{array}$ & $\begin{array}{l}\text { Surgery for patients with } \\
\text { no history of head and neck } \\
\text { treatment }\end{array}$ & $\begin{array}{l}\text { RR: } 68 \% \text { (first-time } \\
\text { surgery), salvage rate for } \\
\text { recurrent tumors: } 66.7 \% \text {, } \\
\text { DFS: } 77.6 \% \text { (5 years) }\end{array}$ & 91 \\
\hline Surgery & 38/M: 36, F: 2 & $\begin{array}{l}1996 \text { to } 2002 / 51 \\
\text { (median) }\end{array}$ & $\begin{array}{l}\text { Staging work-up and } \\
\text { preoperative evaluation } \\
\text { (e.g., computed } \\
\text { tomography of head and } \\
\text { neck area and blood } \\
\text { chemistry) before surgery }\end{array}$ & $\begin{array}{l}\text { RR: } 0, \text { OSR: } 94.7 \% \\
\text { (3 years) }\end{array}$ & 92 \\
\hline Surgery & 40/M: 38, F: 2 & $\begin{array}{l}1991 \text { to } 2002 / 53.8 \\
\text { (average) }\end{array}$ & l & $\begin{array}{l}\text { Control rate: } 94.9 \% \\
\text { (first-time surgery); } \\
\text { OSR: } 89.9 \% \text { ( } 5 \text { years) }\end{array}$ & 93 \\
\hline Surgery & 86/M: 52, F: 34 & $\begin{array}{l}1990 \text { to } 2012 / 64.1 \\
\text { (average) }\end{array}$ & $\begin{array}{l}\text { Enlarged resection of pure } \\
\text { lesions performed in } \\
1.0 \mathrm{~cm} \text { to } 1.5 \mathrm{~cm} \text { outside } \\
\text { the mass edge }\end{array}$ & $\begin{array}{l}\text { RR: } 3.5 \% \text { (first-time } \\
\text { surgery); } 0 \text { (second-time } \\
\text { surgery) ( } 5 \text { years) }\end{array}$ & 94 \\
\hline $\begin{array}{l}\text { Surgery/ } \\
\text { surgery }+ \\
\text { radiation/ } \\
\text { radiation }\end{array}$ & $\begin{array}{l}2350 \text { head and } \\
\text { neck VC }(1314 \\
\text { OVC)/M: } 1410 \text {, } \\
\text { F: } 940\end{array}$ & $\begin{array}{l}1985 \text { to } 1996 / 69 \\
\text { (median) }\end{array}$ & $\begin{array}{l}\text { Early stage: surgery } \\
(85.8 \%) \text {; advanced stage: } \\
\text { surgery }(56.9 \%) \text {, surgery + } \\
\text { radiation }(16.3 \%) \text {, } \\
\text { radiation }(12.5 \%)\end{array}$ & $\begin{array}{l}\text { SR: } 73.7 \% \text { ( } 5 \text { years); for } \\
\text { localized oral cavity } \\
\text { tumors, SR: surgery: } \\
85.7 \% \text {, surgery + } \\
\text { radiation: } 68.4 \% \\
\text { radiation: } 41.8 \% \text { ( } 5 \text { years) }\end{array}$ & 12 \\
\hline Radiotherapy & 53/M: 29, F: 24 & $\begin{array}{l}1985 \text { to } \\
1987 /<35(1.9 \%) ; \\
36-59(47.2 \%) ; \\
>60(50.9 \%)\end{array}$ & $\begin{array}{l}\text { Radiotherapy given either } \\
\text { as external beam } \\
\text { radiotherapy or } \\
\text { interstitial implantation, } \\
\text { or as a combination } \\
\text { of the two }\end{array}$ & $\begin{array}{l}\text { RR: } 30.2 \% \text {; DFS: } 66 \% \text {, } \\
\text { OSR: } 86 \% \text { (5 years); } \\
\text { No anaplastic } \\
\text { transformation in } \\
\text { recurrence cases }\end{array}$ & 97 \\
\hline Radiotherapy & $\begin{array}{l}\text { 107/M: } 75, \\
\mathrm{~F}: 32\end{array}$ & $\begin{array}{l}1977 \text { to } 1987 / 50-59 \\
(37.3 \%) ; 60-69 \\
(27.1 \%)\end{array}$ & $\begin{array}{l}\text { Different stage tumors } \\
\text { receiving different dosage, } \\
\text { fractions, time, and } \\
\text { equipment }\end{array}$ & $\begin{array}{l}\text { SR: } 100 \% \text { (stage I), } 68 \% \\
\text { (stage I1), 35\% (stage 111), } \\
26 \% \text { (stage IV) } \\
\text { (5 years); RR: } 48.6 \%\end{array}$ & 98 \\
\hline $\begin{array}{l}\text { High-dose- } \\
\text { rate (HDR) } \\
\text { brachytherapy }\end{array}$ & $1 / \mathrm{M}$ & $/ 85$ & $\begin{array}{l}\text { A dose of } 48 \text { Gy in } 12 \\
\text { fractions three times } \\
\text { per week }\end{array}$ & $\begin{array}{l}\text { Tumor disappeared } \\
\text { without lymphadenopathy } \\
\text { after } 5 \text { months }\end{array}$ & 99 \\
\hline $\begin{array}{l}\text { Chemotherapy } \\
\text { (methotrexate) }\end{array}$ & 12/M: 3, F: 9 & $\begin{array}{l}1972 \text { to } 2010 / 79 \\
\text { (median) }\end{array}$ & $\begin{array}{l}\text { Different stage tumors } \\
\text { receiving different dosages } \\
\text { by using various routes } \\
\text { (intra-arterial injection, } \\
\text { intramuscular injection and } \\
\text { intravenous injection) }\end{array}$ & $\begin{array}{l}7 \text { patients: good } \\
\text { responses; } 4 \text { patients: } \\
\text { partial responses; } \\
1 \text { patient: no response. } \\
\text { Additional treatments } \\
\text { needed for patients with } \\
\text { no response after one } \\
\text { or two cycles }\end{array}$ & 44 \\
\hline $\begin{array}{l}\text { Chemotherapy } \\
\text { (capecitabine) }\end{array}$ & $2 / \mathrm{F}$ & $1990 / 71 ; 2002 / 75$ & $\begin{array}{l}\text { Two times a day for one } \\
\text { cycle, namely } 2 \text { weeks } \\
\text { on and } 1 \text { week off, at } \\
\text { a dose of } 1000 \mathrm{mg}\end{array}$ & $\begin{array}{l}\text { Both lesions achieving } \\
\text { nearly complete resolution } \\
\text { within } 3 \text { weeks (dramatic } \\
\text { response); time for a } \\
\text { durable partial response: } \\
\text { first patient: } 1 \text { year, } \\
\text { second patient: } 6 \text { months }\end{array}$ & 103 \\
\hline
\end{tabular}


Table II. Continued.

\begin{tabular}{|c|c|c|c|c|c|}
\hline $\begin{array}{l}\text { Treatment } \\
\text { regimen }\end{array}$ & $\begin{array}{c}\text { Number of } \\
\text { patients/gender }\end{array}$ & Time/age & $\begin{array}{l}\text { Specific treatment } \\
\text { modalities and } \\
\text { additional information }\end{array}$ & $\begin{array}{l}\text { Results (recurrence rate, } \\
\text { RR; disease-free survival, } \\
\text { DFS; overall survival } \\
\text { rate, OSR) }\end{array}$ & Refs. \\
\hline $\begin{array}{l}\text { Intra-arterial } \\
\text { chemotherapy } \\
\text { (methotrexate) }\end{array}$ & $15 / \mathrm{M}$ & 155 & $\begin{array}{l}50 \mathrm{mg} \text { per day for a mean } \\
\text { period of } 7.5 \text { days, } \\
\text { followed by } 25 \mathrm{mg} \text { per } \\
\text { week for } 10 \text { weeks }\end{array}$ & $\begin{array}{l}\text { Tumor markedly } \\
\text { regressed and finally } \\
\text { entirely disappeared } \\
\text { after } 2.5 \text { months, } \\
\text { RR: } 0 \text { ( } 43 \text { months) }\end{array}$ & 104 \\
\hline $\begin{array}{l}\text { Intra-arterial } \\
\text { chemotherapy } \\
\text { (methotrexate) }\end{array}$ & $1 / \mathrm{M}$ & $/ 68$ & $\begin{array}{l}25 \mathrm{mg} \text { per day for } 11 \text { days, } \\
\text { folinic acid given } \\
\text { intramuscularly } 6 \mathrm{mg} \text { every } \\
6 \mathrm{~h} \text { during the period }\end{array}$ & $\begin{array}{l}\text { Tumor disappeared after } \\
1.5 \text { months; an ulcer } \\
\text { recurred after } 5 \text { years } \\
\text { and restored by surgical } \\
\text { intervention with } \\
\text { a nasolabial flap }\end{array}$ & 105 \\
\hline Radiochemotherapy & 5/M: $2, \mathrm{~F}: 3$ & 174 (median) & $\begin{array}{l}\text { Radiotherapy (median, } \\
56 \text { Gy) + chemotherapy } \\
\text { (vinblastine } 2 \mathrm{mg} \text { (day 1); } \\
\text { methotrexate } 50 \mathrm{mg} \text { (day } 2 \text {; } \\
\text { bleomycin } 15 \mathrm{mg} \text { (days } 2 \\
\text { and } 3 \text { ), and repetition } \\
\text { at 2-3 week intervals) }\end{array}$ & $\begin{array}{l}5 \text { patients cured and } \\
1 \text { patient died (within } \\
\text { a median } 2.92 \text { years) }\end{array}$ & 106 \\
\hline $\begin{array}{l}\text { Surgery/surgery + } \\
\text { radiochemotherapy }\end{array}$ & 15/M: 5, F: 10 & $\begin{array}{l}1981 \text { to } 1997 / \\
76.9 \text { (average) }\end{array}$ & $\begin{array}{l}\text { One group }(\mathrm{A}) \text { : surgery; } \\
\text { the other group }(\mathrm{B}) \text { : } \\
\text { surgery }+ \\
\text { radiochemotherapy }\end{array}$ & $\begin{array}{l}\text { DSF: A: } 78 \%, \text { B: } 33 \% \\
\text { (5 years); A: } 52 \%, \text { B: } 33 \% \\
\text { (10 years); anaplastic } \\
\text { transformation } \\
\text { occasionally occurred } \\
\text { during treatments of OVC }\end{array}$ & 107 \\
\hline $\begin{array}{l}\text { Surgery/surgery + } \\
\text { chemotherapy, } \\
\text { radiotherapy, } \\
\text { or both }\end{array}$ & 12/M: 5, F: 7 & $\begin{array}{l}1980 \text { to } 2000 / \\
67.8 \pm 3.7 \\
\text { (average) }\end{array}$ & $\begin{array}{l}\text { One group }(\mathrm{A}) \text { : surgery; } \\
\text { the other group }(\mathrm{B}) \text { : } \\
\text { surgery + chemotherapy, } \\
\text { radiotherapy, or both }\end{array}$ & $\begin{array}{l}\text { Local control rate: A: } \\
\text { 86.6\%, B: } 82.1 \% \text {, SR: A: } \\
91.3 \%, \text { B: } 92.3 \% \text { (5 years) }\end{array}$ & 108 \\
\hline $\begin{array}{l}\text { Cryotherapy } \\
\text { and shave } \\
\text { excision }\end{array}$ & $\begin{array}{l}20 \text { (26 lesions: } \\
17 \text { OVH, } \\
9 \text { OVC)/ } \\
\text { M: } 12, \mathrm{~F}: 8\end{array}$ & /45-91 & $\begin{array}{l}\text { Shave excision }+ \text { spraying } \\
\text { liquid nitrogen }(40-50 \text { sec })+ \\
\text { thawing }(30-60 \text { sec })+\text { repeated } \\
\text { freeze-thaw cycle } 3 \text { times }\end{array}$ & $\begin{array}{l}\text { Tumors disappeared and } \\
\text { lesions healed after } \\
\text { 3-4 weeks; RR: } 33.3 \% \\
\text { ( } 23 \text { month); Recurrence } \\
\text { cases cured with the same } \\
\text { technique }\end{array}$ & 112 \\
\hline $\begin{array}{l}\text { Photodynamic } \\
\text { therapy } \\
\text { (PDT) }\end{array}$ & $1 / \mathrm{M}$ & 156 & $\begin{array}{l}\text { Multiple } 3 \text {-min fractionated } \\
\text { irradiations }(1000 \mathrm{sec}) \text { with } \\
\text { a light emitting diode red } \\
\text { light at } 635 \pm 5 \mathrm{~nm}+20 \% \\
5 \text {-aminolevulinic acid }(1.5 \text { or } 2 \mathrm{~h})\end{array}$ & $\begin{array}{l}\text { Extraoral tumor } \\
\text { disappeared after } 6 \text { cycles; } \\
\text { intraoral tumor } \\
\text { disappeared after } \\
22 \text { cycles; no recurrence } \\
\text { within } 6 \text { months }\end{array}$ & 115 \\
\hline $\mathrm{CO}_{2}$ laser therapy & $1 / \mathrm{F}$ & 176 & $\begin{array}{l}\text { One session of } \mathrm{CO}_{2} \text { laser } \\
\text { SmartXide DEKA } \\
\text { (Firenze-Italy) (wave } \\
\text { length: } 10.600 \mathrm{~nm} \text {, power: } \\
8 \mathrm{~W} \text {, repetition rate: } 80 \mathrm{~Hz} \text {, } \\
\text { pulse width: } 1000 \mathrm{msec} \text { ) }\end{array}$ & $\begin{array}{l}\text { No recurrence and } \\
\text { metastasis within the } \\
\text { 2-year follow-up }\end{array}$ & 116 \\
\hline $\mathrm{CO}_{2}$ laser therapy & $2 / \mathrm{F}$ & $2002 / 72 ; 2003 / 70$ & $\begin{array}{l}\text { A focused laser beam } \\
\text { (wave length: } 10.6 \mu \mathrm{m} \text {, } \\
\text { power: } 6 \mathrm{~W})+\mathrm{a} \\
\text { defocused beam }\end{array}$ & $\begin{array}{l}\text { Tumor and lesion } \\
\text { disappeared after } \\
11 \text { months; no recurrence } \\
\text { within } 3 \text { years }\end{array}$ & 117 \\
\hline
\end{tabular}


able for patients in Stage III or IV, the advanced tumor stages which are not an indication for surgery (97). It was shown that the 5-year actuarial survival of patients with OVC treated by primary radiotherapy did not show any significant difference when compared to that of patients treated by surgery (98). In this regard, the role of radiation in promoting anaplastic transformation, a risk which is certainly over-emphasized, seems questionable and warrants further verification. Table II shows representative satisfactory results obtained by using radiotherapy for OVC treatment (97-99). Overall, radiotherapy was deemed less effective but an acceptable alternative treatment regimen for OVC.

Chemotherapy. Up to now, few reports have focused on the efficiency of chemotherapy schemes applied to OVC (100). Surgery and radiation are the major treatments for the exogenic type of OVC. However, for some OVC with strong tendency to local invasion, chemotherapy may be another cost-effective alternative treatment for patients, which usually improves the quality of life considerably. For instance, intra-arterial chemotherapy, featured by convenient dosing, excellent drug activity and acceptable toxicity profile, is effective in some OVC patients. Chemotherapeutic drugs have the capacity to evoke rapid and clinically significant sustained response which can be well tolerated in the patients. Moreover, the persistent and greater exposure of the tumor region to the drugs may induce rapid tumor shrinkage and achieve alleviation in a short time with reduced systemic toxicity $(101,102)$. As shown in Table II, methotrexate and capecitabine are the desirable drugs for OVC treatments (103-105).

Radiochemotherapy. There is a controversy over the outcomes of clinical treatments by radiochemotherapy. For example, Strojan et al reported that the simultaneous intensification of chemotherapy was useful for reducing the radiotherapy dose, which is of benefit to minimization of toxic side effects induced by the treatment (106). Yoshimura et al compared different treatment approaches for 15 patients having OVC at the Shimane Medical University Hospital (107). The results showed that the disease-free survival rates of surgery alone and surgery combined with radiotherapy and chemotherapy were superior to radiotherapy, chemotherapy or their combinations. Surgery was considered the first choice of treatment for OVC, and radiotherapy combined with chemotherapy was regarded as the second most preferable treatment when the patient does not fit for surgery, refuses surgery, or has inoperable tumor. Overall, radiochemotherapy has acceptable therapeutic results (108).

Cryotherapy and shave excision. Cryotherapy is an effective and acceptable treatment method for oral precancerous and cancerous lesions including oral leukoplakia (OL), OVH, OVC and OSCC $(109,110)$. It destroys lesional tissues mainly by disrupting cell membrane and by damaging protein, enzyme and vasculature, resulting in cells swelling, rupturing, or dehydrating. Cryotherapy is capable of reducing blood, scar and pain, and decreasing the occurrence of secondary infections (111). However, cryotherapy does not involve tissue excision and thus lacks precision. It is difficult to judge the final volume of tissue necrosis. Furthermore, OVC lesions are usually bulky and fungating. To obtain complete lesion regression, combined use of cryotherapy and shave excision is demanded (112). In practice, cryotherapy is not the predominant treatment method for OVC, but it is easy, safe, and conservative in OVC treatment.

Photodynamic therapy. Photodynamic therapy (PDT), also known as photochemotherapy (PCT), or phototherapy, was first introduced into oral cancer treatment in the mid-1980s (113). It is a minimally invasive and negligibly toxic technique that has shown great potential in recent years in the treatment of oral precancerous and cancerous lesions, oral premalignant and malignant disorders, including OL, oral erythroleukoplakia (OEL), OVH, OVC, OSCC, and bacterial and fungal infections (114). In general, PDT mediates tumor destruction by three mechanisms. Firstly, the free radicals and singlet oxygen kill tumor cells directly. Secondly, PDT can damage the tumor-associated vasculature, causing thrombus formation and subsequent tumor infarction. Thirdly, PDT-destroyed tumor tissues release tumor specific antigens that activate an immune response against the residual tumor cells. Since PDT has simple procedure with minimal pre-treatment, high efficacy, little or no scar formation, high patient compliance, low invasiveness, and slight side effects, it has played a significant role in the management of OVC (Table II) (115).

$\mathrm{CO}_{2}$ laser therapy. Since the early 1970 s, carbon dioxide $\left(\mathrm{CO}_{2}\right)$ laser therapy has been introduced to treat patients having oral lesions. The advantages of this treatment include short surgical time, effective wound sterilization, fast hemostasis and healing process, little pain, sealing of adjacent lymphatic vessels, reduced spread of malignant cells and anti-metastasis. These advantages have been partially confirmed by reported studies in Table II $(116,117)$.

\section{Discussion}

OVC has received increasing attention in the past decades, which has been demonstrated by much effort spent on its etiology, clinical manifestations, pathology, diagnosis and treatment. There were evident advancements in this field, covering from etiological analysis to effective treatment. In particular, exploration of molecular mechanism and diagnosis of OVC have been largely promoted by employing multiple biomarkers. With advancement of understanding of the mechanism and diagnosis, various treatment regimens have been developed for OVC patients. The most notable ones include surgery, radiotherapy, and chemotherapy, which have already showed desired results in many cases. Other unconventional modalities such as cryotherapy and shave excision, photodynamic therapy, laser and immune therapies further enhanced the treatment effectiveness although they were often recognized as a means of auxiliary approach. Without doubt, these progresses will warrant effective prevention and better treatment of OVC. However, it should be noted that this field is still facing three challenges from primary sub-fields of the research and clinical practice of OVC, namely multifactorial etiology, complex molecular mechanism, and deficient treatment (Fig. 1). To resolve these challenges, more effort on the multifactorial etiology analysis, incorporation of effective biomarkers for mechanism illustra- 


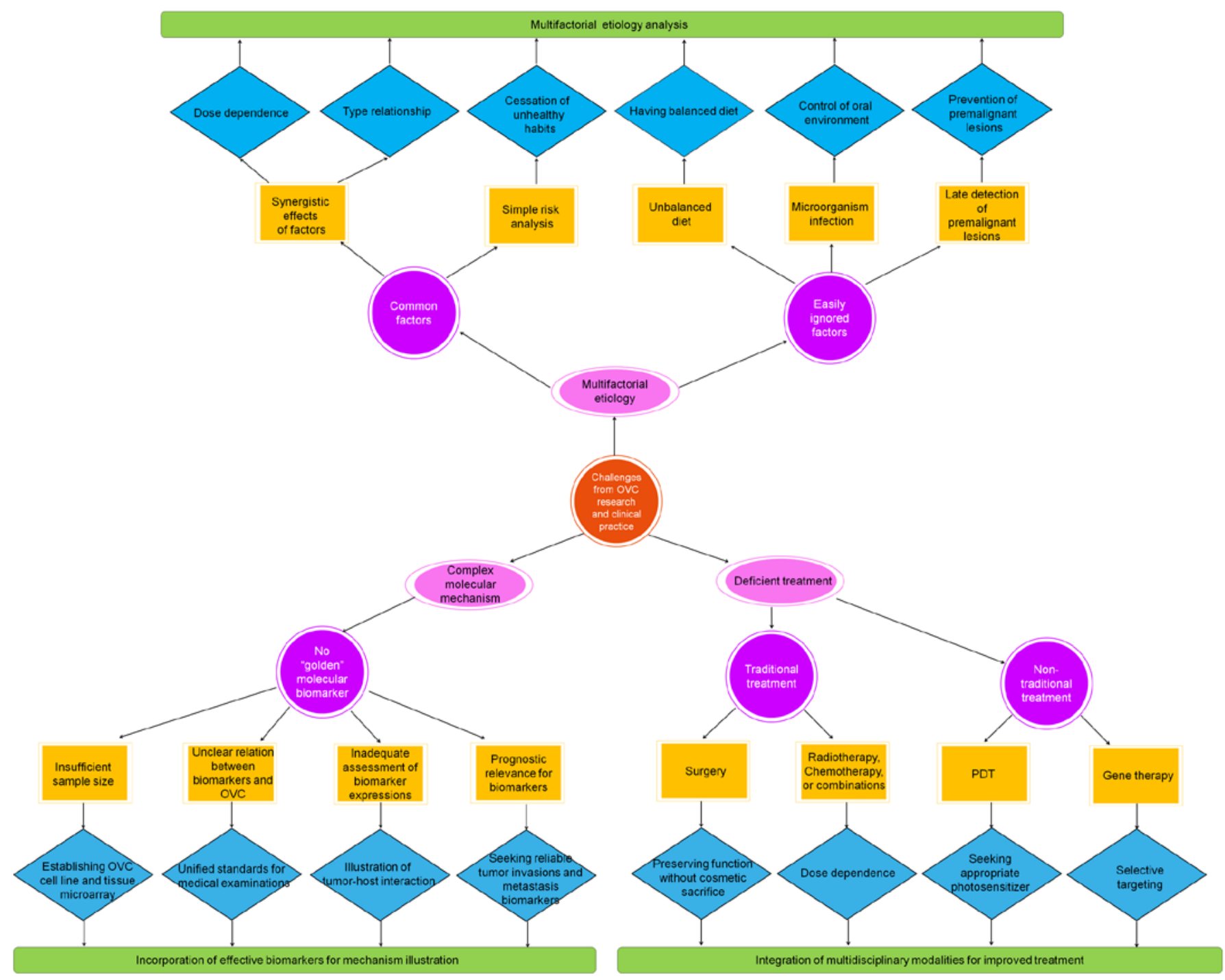

Figure 1. Challenges and potential solutions for research and clinical practice of OVC.

tion, and integration of multidisciplinary modalities for improved treatment is desired.

Multifactorial etiology analysis. As aforementioned, the etiology of OVC is multifactorial. The most important etiological factors are excess consumption of alcohol, tobacco, and areca nut usage. However, it was difficult to explain the increasing incidence of OVC with those common risk factors alone. This is because, on the one hand, these factors often act synergistically and therefore, their dose-dependence and type relationship are hard to determine. On the other hand, there is a lack of detailed risk analysis of these habits. The cessation of these habits may prevent the development of second primary tumors that arise independently, but it is useless for multiple primary tumors that are caused by migration of already transformed clone of cells (118).

Apart from the above risk factors, other factors that predispose towards the development of OVC involve unbalanced diet, i.e., an antioxidant-deficient diet. This finding can be demonstrated by the advantages of consumption of fruit and vegetables. Another easily ignored factor in association with OVC, as discussed in the etiology section, is microorganism infection, which requires control of oral environment. Microbes have the potential of being used as a diagnostic indicator although the relationship between microflora and oral malignancy, and how microorganisms interact with the oral mucosa at a cellular level deserve further investigation. Finally, late detection of premalignant oral lesions has evolved into another important etiological factor. Successful inhibition of development of premalignant oral lesions toward OVC would considerably reduce the risk of OVC. This can be achieved by combining commercial diagnostic aids and adjunctive techniques besides conventional oral examination for screening of patients for signs of oral cancer and precancerous lesions. A large number of oral cancer screening and case-finding aids or adjuncts (e.g., toluidine blue, brush cytology, tissue reflectance and autofluorescence) have already been developed and used to assist in the screening of healthy patients for evidence of occult cancerous change or to assess the biologic potential of clinically abnormal mucosal lesions $(119,120)$. Altogether, it is necessary to enforce multifactorial etiology analysis to reduce the morbidity and even mortality of OVC. 
Incorporation of effective biomarkers for mechanism illustration. There is no doubt that the molecular mechanism of OVC remains the focus of attention. To further the understanding of the mechanism, reliable molecular markers associated with the occurrence, progression and prognosis of OVC should be sought regarding the complexity of oral carcinogenesis. For this goal, various molecular markers have been proposed for use. However, clear molecular markers as a golden diagnostic standard are still absent. This fact is attributed to several reasons. Firstly, due to insufficient sample size, some markers showed low predictive values which fail to reach significance. It is thus necessary to establish an OVC cell line and tissue microarray. Secondly, incomplete knowledge for the relation between biomarkers and OVC may cause 'superficial' understanding of their roles, which are often questionable (121). Taking VEGF as an example, there is no identified close correlation between its expression and microvessel density (MVD) (122). Prior work showed the oral carcinomas did not react to experimental anti-angiogenetic therapy and the mean MVD revealed no relationship with the survival rate (123). Thirdly, the assessment of role of expressions of biomarkers like proteins is inadequate. The expressions appear to be more important than the markers themselves. A good example is p53, whose molecules up- or downstream on the apoptotic pathway were found to be more important. It indicates that further exploration of the field has to consider the tumor-host interaction. Fourthly, the prognostic relevance, usually evaluated based on a long-term follow-up, has not been provided for evaluation of markers of the tumor invasion and metastasis (e.g., MMPs). Since the relevance may illustrate another area of local interaction between oral cancer and its host in utilizing proteolytic enzymes for peritumoral matrix degradation and tumor spread, it actually indicates another direction for seeking reliable biomarkers. Overall, more attention should be directed at the role of molecular markers for deep understanding of the molecular mechanism of OVC, which essentially requires good incorporation of effective biomarkers in association with histopathology, molecular profiling with well-established clinical parameters, and prognostic analysis.

Integration of multidisciplinary modalities for improved treatment. In principle, the choice of treatment for OVC depends on many factors. Current clinical applications involve use of a variety of treatment modes. The most extensively used regimens are surgery, radiotherapy, chemotherapy and radiochemotherapy, which, as discussed before, have already showed desired results. Specifically, surgery represents the first choice of treatment for OVC. It aims at preserving functions without cosmetic sacrifice and its efficacy relies on multiple factors including primary site, location, size, proximity to bone, and depth of infiltration. For example, the use of marginal mandibulectomy and mandibulotomy for tumors that approach or involve the mandible requires special attention to the mechanism of bone involvement. The success of surgery also depends on the role of the surgeon which represents an unnegligible factor throughout the life history of an OVC patient and on the techniques involved during surgery. Advanced technologies, such as rapid prototyping combined with X-ray tomography, are expected to remedy the disadvantages of surgery (124-126). For radiotherapy, chemotherapy, and radiochemotherapy, they are usually regarded as the next most preferable treatment when surgery is inappropriate. Employment of either or both of them will contribute to the increase of the overall survival of patients with OVC once dose dependencies of radiation and drugs associated with the drug delivery system are established (127).

Despite considerable advances in the above traditional modalities, the survival of patients with OVC still needs improvement. Unconventional approaches provide alternative ways for treatment of OVC. Among them, PDT is especially promising because of its better prognosis than radiotherapy and chemoradiotherapy (128). For application of PDT, an ideal photosensitizer should be administered easily and safely, targeted appropriately, illuminated and activated at clinically useful wavelengths, pain-free, and obtained easily to achieve apoptosis and tumor necrosis with vascular cessation for clinical operation. The success of PDT also requires accurate dosimetry and suitable illumination devices and sufficiently defined treatment parameters. Thus, interactions between clinical applications and technological innovations and interdisciplinary research approaches should be pursued to overcome the difficulties and challenges for PDT.

Gene therapy is another very promising method as it introduces new genetic material into targeted cells without poisoning non-targeted tissues for treatment (129). The general strategies utilized in a gene therapy approach for cancer include gene addition therapy, gene excision therapy, antisense RNA technique, immunotherapy, 'suicide' gene therapy. For OVC, gene therapy is currently under investigation in clinical trials (130). Although it has a rather high requirement for selective targeting of tumor cells associated with multiple etiological factors, exploitation of the principle and selective targeting of tumor cells are feasible as our understanding of the molecular mechanisms of OVC progresses. Also, regarding that OVC is an attractive tumor target due to its frequent genetic mutations and accessibility for intratumoral administration, the safety and efficacy of gene therapy for prevention and treatment of OVC can be further enhanced by phase clinical studies and trials.

Overall, as OVC is characterized by multifactorial etiology and incomplete understanding of molecular mechanism, a variety of treatment modalities exist and may complement one another well. Integration of multidisciplinary modalities, such as surgery, chemotherapy, radiotherapy and/or unconventional methods, either sequentially or concurrently is highly recommended for OVC treatment.

\section{Conclusions}

As a verrucous variant of OSCC, OVC has received increasing attention recently. This paper offers a systematic review on its etiology, clinical manifestations and pathology, molecular mechanism, diagnosis and differential diagnosis and treatment. It clearly shows that the enormous effort spent in the past decades has contributed to significant advancements in this field, ranging from etiological analysis to development of various regimens for treatment. Nevertheless, this field also faces three great challenges from primary sub-fields of the research and clinical practice of OVC, namely multifactorial etiology, complex molecular mechanism, and deficient treatment. 
From the point of view of etiology, common risk factors alone cannot adequately account for the increasing incidence of OVC. Instead, other factors that predispose towards the development of OVC, namely unbalanced diet, microorganism infection, and late detection of premalignant oral lesions, warrant further analysis. From the perspective of the molecular mechanism of OVC, incorporation of effective biomarkers in association with histopathology and molecular profiling with well-established clinical parameters, and prognostic analysis of OVC deserves more attention for deep understanding of the mechanism. Lastly, to promote effectiveness and efficacy of OVC treatment, it is necessary to integrate multidisciplinary modalities, such as surgery, chemotherapy, radiotherapy and/or unconventional methods (e.g., PDT), either sequentially or concurrently considering their potential complements to each other. In brief, continuous effort on the multifactorial etiology analysis and molecular mechanism through pursuing effective biomarkers will offer key insights into OVC pathogenesis which leads the treatment with integration of multidisciplinary modalities.

\section{Acknowledgements}

This work was partially supported by the Natural Science Foundation of Qinghai Province of China (Grant 2013-z-908), the National Natural Science Foundation of China (Grant 81300841) and the Grant from Science and Technology Department of Hunan Province of China (Grant 2013SK5075). The authors would like to extend their sincere appreciation to Dr Shan Gao at Suzhou Ribo Life Science Co. Ltd and Dr Zhiwei Peng at School of Minerals Processing and Bioengineering, Central South University for helpful discussions.

\section{References}

1. Jemal A, Bray F, Center MM, Ferlay J, Ward E and Forman D Global cancer statistics. CA Cancer J Clin 61: 69-90, 2011.

2. Fujii M: Multidisciplinary approach for the treatment of head and neck cancer. Int J Clin Oncol 19: 209-210, 2014.

3. Rivera $\mathrm{C}$ and Venegas B: Histological and molecular aspects of oral squamous cell carcinoma (Review). Oncol Lett 8: 7-11, 2014.

4. Chaisuparat R, Limpiwatana S, Kongpanitkul S, Yodsanga S and Jham BC: The Akt/mTOR pathway is activated in verrucous carcinoma of the oral cavity. J Oral Pathol Med: Jan 17, 2016 (Epub ahead of print).

5. Kamala K, Sankethguddad S and Sujith SG: Verrucous carcinoma of oral cavity - a case report with review of literature. IJHSR 5 : 330-334, 2015.

6. Gokavarapu S, Parvataneni N, Charan CR, Puthamakula S, Kulkarni G and Reddy BS: Multi centricity of oral verrucous carcinoma: A case series of 22 cases. Indian J Otolaryngol Head Neck Surg 67: 138-142, 2015

7. Ackerman LV: Verrucous carcinoma of the oral cavity. Surgery 23: 670-678, 1948

8. Wang Y, Wu QG and Zhen LF: Clinical pathology study of oral verrucous carcinoma. Chin J Stomatol 20: 65-68, 1985.

9. Tang ZG, Li JY, Su T, Yao ZG, Shen ZH and Li HB: The clinic study on oral verrucous carcinoma. J Oral Maxillofac Surg 12: $87-88,2002$.

10. Rahali L, Omor Y, Mouden K, Mahdi Y, Elkacemi H, Elmajjaoui S, Latib R, Kebdani T, Boujida MN and Benjaafar N: Oral verrucous carcinoma complicating a repetitive injury by the dental prosthesis: A case report. Pan Afr Med J 20: 297, 2015.

11. Zargaran M, Eshghyar N, Baghaei F and Moghimbeigi A Assessment of cellular proliferation in oral verrucous carcinoma and well-differentiated oral squamous cell carcinoma using Ki67: A non-reliable factor for differential diagnosis? Asian Pac J Cancer Prev 13: 5811-5815, 2012.
12. Koch BB, Trask DK, Hoffman HT, Karnell LH, Robinson RA, Zhen W and Menck HR; Commission on Cancer, American College of Surgeons; American Cancer Society: National survey of head and neck verrucous carcinoma: Patterns of presentation, care, and outcome. Cancer 92: 110-120, 2001.

13. Vallonthaiel AG, Singh MK, Dinda AK, Kakkar A, Thakar A and Das SN: Expression of cell cycle associated proteins p53, $\mathrm{pRb}, \mathrm{p} 16, \mathrm{p} 27$ and correlation with survival: A comparative study on squamous cell carcinoma and verrucous carcinoma. Appl Immunohistochem Mol Morphol 24: 193-200, 2016.

14. Tang Z, Xie X, Li J, Liu X, Yao Z and Zhao S: A clinic study on oral verrucous carcinoma phenotypes. Chin J Dent Res 8: 57-61, 2005.

15. Pravda C, Srinivasan H, Koteeswaran D and Manohar LA: Verrucous carcinoma in association with oral submucous fibrosis. Indian J Dent Res 22: 615, 2011.

16. Joshi P, Dutta S, Chaturvedi P and Nair S: Head and neck cancers in developing countries. Rambam Maimonides Med J 5: e0009, 2014.

17. Agnihotri A and Agnihotri D: Verrucous carcinoma: A study of 10 cases. Indian J Oral Sci 3: 79-83, 2012.

18. Schutze M, Boeing H, Pischon T, Rehm J, Kehoe T, Gmel G, Olsen A, Tjønneland AM, Dahm CC, Overvad K, et al: Alcohol attributable burden of incidence of cancer in eight European countries based on results from prospective cohort study. BMJ 342: d1584, 2011.

19. Johnson N: Tobacco use and oral cancer: A global perspective. J Dent Educ 65: 328-339, 2001.

20. Zhang X and Reichart PA: A review of betel quid chewing, oral cancer and precancer in Mainland China. Oral Oncol 43: 424-430, 2007.

21. Ahn J, Chen CY and Hayes RB: Oral microbiome and oral and gastrointestinal cancer risk. Cancer Causes Control 23: 399-404, 2012.

22. Gupta S, Kumar K, Raviprakash SM and Arunkumar KV: Ackerman's tumor of the oral cavity: A study of four cases with its conglomerate appearance. J Dent Specialities 3: 92-95, 2015.

23. La Vecchia C, Tavani A, Franceschi S, Levi F, Corrao G and Negri E: Epidemiology and prevention of oral cancer. Oral Oncol 33: 302-312, 1997.

24. Andrade JO, Santos CA and Oliveira MC: Associated factors with oral cancer: A study of case control in a population of the Brazil's Northeast. Rev Bras Epidemiol 18: 894-905, 2015 (In Portuguese).

25. Aslesh OP, Paul S, Paul L and Javasree AK: High prevalence of tobacco use and associated oral mucosal lesion among interstate male migrant workers in urban Kerala, India. Iran J Cancer Prev 8: e3876, 2015.

26. Al-Jaber A, Al-Nasser L and El-Metwally A: Epidemiology of oral cancer in Arab countries. Saudi Med J 37: 249-255, 2016.

27. Langevin F, Crossan GP, Rosado IV, Arends MJ and Patel KJ: Fancd 2 counteracts the toxic effects of naturally produced aldehydes in mice. Nature 475: 53-58, 2011.

28. Verna L, Whysner J and Williams GM: N-nitrosodiethylamine mechanistic data and risk assessment: Bioactivation, DNA-adduct formation, mutagenicity, and tumor initiation. Pharmacol Ther 71: 57-81, 1996.

29. Lee SY, Cho NH, Choi EC, Baek SJ, Kim WS, Shin DH and Kim SH: Relevance of human papilloma virus (HPV) infection to carcinogenesis of oral tongue cancer. Int J Oral Maxillofac Surg 39: 678-683, 2010.

30. Campisi G and Giovannelli L: Controversies surrounding human papilloma virus infection, head \& neck vs oral cancer, implications for prophylaxis and treatment. Head Neck Oncol 1: 8, 2009.

31. Herrero R, Castellsagué X, Pawlita M, Lissowska J, Kee F, Balaram P, Rajkumar T, Sridhar H, Rose B, Pintos J, et al; IARC Multicenter Oral Cancer Study Group: Human papillomavirus and oral cancer: The International Agency for Research on Cancer multicenter study. J Natl Cancer Inst 95: 1772-1783, 2003.

32. Samman M and Sethi N: Oral verrucous pre-malignant lesions and HPV. Clin Otolaryngol 40: 292-293, 2015.

33. del Pino M, Bleeker MC, Quint WG, Snijders PJ, Meijer CJ and Steenbergen RD: Comprehensive analysis of human papillomavirus prevalence and the potential role of low-risk types in verrucous carcinoma. Mod Pathol 25: 1354-1363, 2012.

34. Noble-Topham SE, Fliss DM, Hartwick RW, McLachlin CM, Freeman JL, Noyek AM and Andrulis IL: Detection and typing of human papillomavirus in verrucous carcinoma of the oral cavity using the polymerase chain reaction. Arch Otolaryngol Head Neck Surg 119: 1299-1304, 1993. 
35. Fujita S, Senba M, Kumatori A, Hayashi T, Ikeda T and Toriyama K: Human papillomavirus infection in oral verrucous carcinoma: Genotyping analysis and inverse correlation with p53 expression. Pathobiology 75: 257-264, 2008.

36. de Spíndula-Filho JV, da Cruz AD, Oton-Leite AF, Batista AC Leles CR, de Cássia Gonçalves Alencar R, Saddi VA and Mendonça EF: Oral squamous cell carcinoma versus oral verrucous carcinoma: An approach to cellular proliferation and negative relation to human papillomavirus (HPV). Tumour Biol 32: 409-416, 2011.

37. Patel KR, Chernock RD, Zhang TR, Wang X, El-Mofty SK and Lewis JS Jr: Verrucous carcinomas of the head and neck, including those with associated squamous cell carcinoma, lack transcriptionally active high-risk human papillomavirus. Hum Pathol 44: 2385-2392, 2013.

38. Samman M, Wood H, Conway C, Berri S, Pentenero M, Gandolfo S, Cassenti A, Cassoni P, Al Ajlan A, Barrett AW, et al: Next-generation sequencing analysis for detecting human papillomavirus in oral verrucous carcinoma. Oral Surg Oral Med Oral Pathol Oral Radiol 118: 117-125.e1, 2014.

39. Waskowska J, Koszowski R, Raczkowska-Siostrzonek A and Stemplewska K: Verrucous carcinoma of the tongue-a rare case study. Cent Eur J Med 7: 145-148, 2012.

40. Rodrigues J, Vaz OP, Salelkar RS, Ramani A, Falari S and Veeresh HM: A rare case of verrucous carcinoma on the dorsum of the tongue. Int J Adv Case Rep 2: 530-531, 2015.

41. Garcia NG, Oliveira DT, Hanemann JA and Pereira AA: Oral verrucous carcinoma mimicking a chronic candidiasis: A case report. Case Rep Oncol Med 2012: 190272, 2012.

42. Alkan A, Bulut E, Gunhan O and Ozden B: Oral verrucous carcinoma: A study of 12 cases. Eur J Dent 4: 202-207, 2010.

43. Liu O, Zhang H, Wang Y, Quan H, Zhang J, Zhou J, Zuo J, Tang J, Fang X, Wang W, et al: Stereology study of oral verrucous carcinoma. J BUON 17: 343-349, 2012.

44. Karagozoglu KH, Buter J, Leemans CR and Rietveld DH, van den Vijfeijken S and van der Waal I: Subset of patients with verrucous carcinoma of the oral cavity benefit from treatment with methotrexate. Br J Oral Maxillofac Surg 50: 513-518, 2012.

45. Terada T: Multiple verrucous carcinomas of the oral cavity. J Maxillofac Oral Surg 14 (Suppl 1): 393-396, 2015.

46. Angadi VC and Angadi PV: GLUT-1 immunoexpression in oral epithelial dysplasia, oral squamous cell carcinoma, and verrucous carcinoma. J Oral Sci 57: 115-122, 2015.

47. Mallick S, Breta M, Gupta SD, Dinda AK, Mohanty BK and Singh MK: Angiogenesis, proliferative activity and DNA ploidy in oral verrucous carcinoma: A comparative study including verrucous hyperplasia and squamous cell carcinoma. Pathol Oncol Res 21: 1249-1257, 2015.

48. Samman M, Wood HM, Conway C, Stead L, Daly C, Chalkley R, Berri S, Senguven B, Ross L, Egan P, et al: A novel genomic signature reclassifies an oral cancer subtype. Int J Cancer 137: 2364-2373, 2015

49. Wang YH, Tian X, Liu OS, Fang XD, Quan HZ, Xie S, Gao S and Tang ZG: Gene profiling analysis for patients with oral verrucous carcinoma and oral squamous cell carcinoma. Int J Clin Exp Med 7: 1845-1852, 2014.

50. Burgio E and Migliore L: Towards a systemic paradigm in carcinogenesis: Linking epigenetics and genetics. Mol Biol Rep 42: 777-790, 2015.

51. Patil GB, Hallikeri KS, Balappanavar AY, Hongal SG, Sanjaya PR and Sagari SG: Cyclin B1 overexpression in conventional oral squamous cell carcinoma and verrucous carcinoma- A correlation with clinicopathological features. Med Oral Patol Oral Cir Bucal 18: e585-e590, 2013 .

52. Angadi PV and Krishnapillai R: Cyclin D1 expression in oral squamous cell carcinoma and verrucous carcinoma: Correlation with histological differentiation. Oral Surg Oral Med Oral Pathol Oral Radiol Endod 103: e30-e35, 2007.

53. Sakurai K, Urade M, Takahashi Y, Kishimoto H, Noguchi K, Yasoshima $\mathrm{H}$ and Kubota A: Increased expression of c-erbB-3 protein and proliferating cell nuclear antigen during development of verrucous carcinoma of the oral mucosa. Cancer 89: 2597-2605, 2000.

54. Terada T: Squamous cell carcinoma arising within verrucous carcinoma of the oral cavity: A case report. Int J Clin Exp Pathol 5: 363-366, 2012

55. Quan H, Tang Z, Zhao L, Wang Y, Liu O, Yao Z and Zuo J: Expression of $\alpha \mathrm{B}$-crystallin and its potential anti-apoptotic role in oral verrucous carcinoma. Oncol Lett 3: 330-334, 2012.
56. Wang RQ and Tang ZG: Expression of Skp2 and p27 in oral verrucous carcinoma. J Oral Sci Res 30: 230-234, 2014.

57. Mohtasham N, Babakoohi S, Shiva A, Shadman A, KamyabHesari K, Shakeri MT and Sharifi-Sistani N: Immunhistochemical study of p53, Ki-67, MMP-2 and MMP-9 expression at invasive front of squamous cell and verrucous carcinoma in oral cavity. Pathol Res Pract 209: 110-114, 2013.

58. Odar K, Kocjan BJ, Hošnjak L, Gale N, Poljak M and Zidar N: Verrucous carcinoma of the head and neck - not a human papillomavirus-related tumour? J Cell Mol Med 18: 635-645, 2014.

59. Saito T, Nakajima $\mathrm{T}$ and Mogi K: Immunohistochemical analysis of cell cycle-associated proteins p16, pRb, p53, p27 and Ki-67 in oral cancer and precancer with special reference to verrucous carcinomas. J Oral Pathol Med 28: 226-232, 1999.

60. Lin HP, Wang YP and Chiang CP: Expression of p53, MDM2, p21, heat shock protein 70, and HPV 16/18 E6 proteins in oral verrucous carcinoma and oral verrucous hyperplasia. Head Neck 33: 334-340, 2011.

61. Odar K, Boštjančič E, Gale N, Glavač D and Zidar N: Differential expression of microRNAs miR-21, miR-31, miR-203, miR$125 a-5 p$ and miR-125b and proteins PTEN and p63 in verrucous carcinoma of the head and neck. Histopathology 61: 257-265, 2012.

62. Ray JG, Mukherjee S, Pattanayak Mohanty S and Chaudhuri K: Oral verrucous carcinoma - a misnomer? Immunohistochemistry based comparative study of two cases. BMJ Case Rep 2011: bcr1120103479, 2011.

63. Chen YK, Hsuen SS and Lin LM: Increased expression of inducible nitric oxide synthase for human oral submucous fibrosis, verrucous hyperplasia, and verrucous carcinoma. Int J Oral Maxillofac Surg 31: 419-422, 2002.

64. Chawla H, Urs AB and Augustine J: Association of macrophages with angiogenesis in oral epithelial dysplasia, oral verrucous carcinoma, and oral squamous cell carcinoma: An immunohistochemical study. Appl Immunohistochem Mol Morphol Dec 9, 2015 (Epub ahead of print).

65. Al-Azri AR, Gibson RJ, Bowen JM, Stringer AM, Keefe DM and Logan RM: Involvement of matrix metalloproteinases (MMP-3 and MMP-9) in the pathogenesis of irinotecan-induced oral mucositis. J Oral Pathol Med 44: 459-467, 2015.

66. Kerkelä E, Ala-aho R, Klemi P, Grénman S, Shapiro SD, Kähäri VM and Saarialho-Kere U: Metalloelastase (MMP-12) expression by tumour cells in squamous cell carcinoma of the vulva correlates with invasiveness, while that by macrophages predicts better outcome. J Pathol 198: 258-269, 2002.

67. Ala-aho R, Grénman R, Seth P and Kähäri VM: Adenoviral delivery of $\mathrm{p} 53$ gene suppresses expression of collagenase-3 (MMP-13) in squamous carcinoma cells. Oncogene 21: $1187-1195,2002$.

68. Lawal AO, Adisa AO, Kolude B and Adeyemi BF: Immunohistochemical expression of MMP-2 and MMP-8 in oral squamous cell carcinoma. J Clin Exp Dent 7: e203-e207, 2015.

69. Kierszenbaum AL and Tres L: Histology and Cell Biology, an Introduction to Pathology. 3rd edition. Elsevier, Philadelphia, PA, 2012.

70. van der Zee JA, van Eijck CHJ, Hop WCJ, Biermann K, Dicheva BM, Seynhaeve ALB, Koning GA, Eggermont AM and Ten Hagen TL: Tumour basement membrane laminin expression predicts outcome following curative resection of pancreatic head cancer. Br J Cancer 107: 1153-1158, 2012.

71. Impola U, Uitto VJ, Hietanen J, Hakkinen L, Zhang L, Larjava H, Isaka $\mathrm{K}$ and Saarialho-Kere U: Differential expression of matrilysin-1 (MMP-7), 92 kD gelatinase (MMP-9), and metalloelastase (MMP-12) in oral verrucous and squamous cell cancer. J Pathol 202: 14-22, 2004.

72. Kadeh H, Saravani S, Heydari F, Keikha M and Rigi V: Expression of matrix metalloproteinase-10 at invasive front of squamous cell carcinoma and verrucous carcinoma in the oral cavity. Asian Pac J Cancer Prev 16: 6609-6613, 2015.

73. Arduino PG, Carrozzo M, Pagano M, Broccoletti R, Scully C and Gandolfo S: Immunohistochemical expression of basement membrane proteins of verrucous carcinoma of the oral mucosa. Clin Oral Investig 14: 297-302, 2010.

74. Kobayashi H, Sagara J, Masumoto J, Kurita H, Kurashina K and Taniguchi S: Shifts in cellular localization of moesin in normal oral epithelium, oral epithelial dysplasia, verrucous carcinoma and oral squamous cell carcinoma. J Oral Pathol Med 32: 344-349, 2003. 
75. Zargaran M, Eshghyar N, Vaziri PB and Mortazavi H: Immunohistochemical evaluation of type IV collagen and laminin-332 $\gamma 2$ chain expression in well-differentiated oral squamous cell carcinoma and oral verrucous carcinoma: A new recommended cut-off. J Oral Pathol Med 40: 167-173, 2011.

76. Kolokythas A, Rogers TM and Miloro M: Hybrid verrucous squamous carcinoma of the oral cavity: Treatment considerations based on a critical review of the literature. J Oral Maxillofac Surg 68: 2320-2324, 2010.

77. Ho PS, Chen PL, Warnakulasuriya S, Shieh TY, Chen YK and Huang IY: Malignant transformation of oral potentially malignant disorders in males: A retrospective cohort study. BMC Cancer 9: 260-267, 2009.

78. Hsue SS, Wang WC, Chen CH, Lin CC, Chen YK and Lin LM: Malignant transformation in 1458 patients with potentially malignant oral mucosal disorders: A follow-up study based in a Taiwanese hospital. J Oral Pathol Med 36: 25-29, 2007.

79. Paral KM, Taxy JB and Lingen MW: CD34 and $\alpha$ smooth muscle actin distinguish verrucous hyperplasia from verrucous carcinoma. Oral Surg Oral Med Oral Pathol Oral Radiol 117: 477-482, 2014

80. Habiba U, Kitamura T, Yanagawa-Matsuda A, Hida K, Higashino F, Ohiro Y, Totsuka Y and Shindoh M: Cytoplasmic expression of HuR may be a valuable diagnostic tool for determining the potential for malignant transformation of oral verrucous borderline lesions. Oncol Rep 31: 1547-1554, 2014

81. Alan H, Agacayak S, Kavak G and Ozcan A: Verrucous carcinoma and squamous cell papilloma of the oral cavity: Report of two cases and review of literature. Eur J Dent 9: 453-456, 2015.

82. Oliveira MC, Silveira EJ, Godoy GP, Amorim RF, Costa AL and Queiroz LM: Immunohistochemical evaluation of intermediate filament proteins in squamous papilloma and oral verrucous carcinoma. Oral Dis 11: 288-292, 2005.

83. Klieb HBE and Raphael SJ: Comparative study of the expression of p53, Ki67, E-cadherin and MMP-1 in verrucous hyperplasia and verrucous carcinoma of the oral cavity. Head Neck Pathol 1: 118-122, 2007.

84. Pentenero M, Donadini A, Di Nallo E, Maffei M, Marino R, Familiari U, Broccoletti R, Castagnola P, Gandolfo S and Giaretti W: Distinctive chromosomal instability patterns in oral verrucous and squamous cell carcinomas detected by highresolution DNA flow cytometry. Cancer 117: 5052-5057, 2011.

85. Gokavarapu S, Rao S LM, Tantravahi US, Gundimeda SD, Rao TS and Murthy S: Oral hybrid verrucous carcinoma: A clinical study. Indian J Surg Oncol 5: 257-262, 2014.

86. Gokavarapu S, Chandrasekhara Rao LM, Patnaik SC, Parvataneni N, Raju KV, Chander R and Kumar KA: Reliability of incision biopsy for diagnosis of oral verrucous carcinoma: A multivariate clinicopathological study. J Maxillofac Oral Surg 14: 599-604, 2015

87. Verma DK, Bansal S, Gupta D and Bansal A: Neck dissection in verrucous carcinoma: A surgical dilemma. IJSS Case Rep Rev 1: 42-45, 2015 .

88. Sadasivan A, Thankappan K, Rajapurkar M, Shetty S, Sreehari S and Iyer S: Verrucous lesions of the oral cavity treated with surgery: Analysis of clinico-pathologic features and outcome. Contemp Clin Dent 3: 60-63, 2012.

89. Sciubba JJ and Helman JI: Current management strategies for verrucous hyperkeratosis and verrucous carcinoma. Oral Maxillofac Surg Clin North Am 25: 77-82, 2013.

90. Candau-Alvarez A, Dean-Ferrer A, Alamillos-Granados FJ, Heredero-Jung S, García-García B, Ruiz-Masera JJ, ArévaloArévalo R, Zafra-Camacho F and Valenzuela-Salas B: Verrucous carcinoma of the oral mucosa: An epidemiological and follow-up study of patients treated with surgery in 5 last years. Med Oral Patol Oral Cir Bucal 19: e506-e511, 2014.

91. Walvekar RR, Chaukar DA, Deshpande MS, Pai PS, Chaturvedi P, Kakade A, Kane SV and D'Cruz AK: Verrucous carcinoma of the oral cavity: A clinical and pathological study of 101 cases. Oral Oncol 45: 47-51, 2009.

92. Kang CJ, Chang JTC, Chen TM, Chen IH and Liao CT: Surgical treatment of oral verrucous carcinoma. Chang Gung Med J 26: 807-812, 2003.

93. Huang TT, Hsu LP, Hsu YH and Chen PR: Surgical outcome in patients with oral verrucous carcinoma: Long-term follow-up in an endemic betel quid chewing area. ORL J Otorhinolaryngol Relat Spec 71: 323-328, 2009.

94. Wang Z, Li DX, Liu MD, Zhong M and Sun CF: Eighty-six cases of oral verrucous carcinomaclinical and pathological analysis. Chin J Pract Stomatol 7: 367-369, 2014.
95. Proffitt SD, Spooner TR and Kosek JC: Origin of undifferentiated neoplasm from verrucous epidermal carcinoma of oral cavity following irradiation. Cancer 26: 389-393, 1970.

96. Ferlito A, Rinaldo A and Mannarà GM: Is primary radiotherapy an appropriate option for the treatment of verrucous carcinoma of the head and neck? J Laryngol Otol 112: 132-139, 1998.

97. Vidyasagar MS, Fernandes DJ, Kasturi DP, Akhileshwaran R, Rao K, Rao S, Rao RV and Solomon JG: Radiotherapy and verrucous carcinoma of the oral cavity. A study of 107 cases. Acta Oncol 31: 43-47, 1992.

98. Jyothirmayi R, Sankaranarayanan R, Varghese C, Jacob R and Nair MK: Radiotherapy in the treatment of verrucous carcinoma of the oral cavity. Oral Oncol 33: 124-128, 1997.

99.van Gestel KM, Buurman DJ, Pijls R, Kessler PA, van den Ende PL, Hoffmann AL and Troost EG: Locally advanced verrucous carcinoma of the oral cavity: Treatment using customized mold HDR brachytherapy instead of hemimaxillectomy. Strahlenther Onkol 189: 894-898, 2013.

100. Tanaka J, Yoshida K, Takahashi M and Suzuki M: A case of verrucous carcinoma of the tongue, effectively treated with preoperative chemotherapy (UFT, CDDP, PEP) and irradiation. Gan To Kagaku Ryoho 19: 525-527, 1992 (In Japanese).

101. Galmarini FC, Galmarini CM, Sarchi MI, Abulafia J and Galmarini D: Heterogeneous distribution of tumor blood supply affects the response to chemotherapy in patients with head and neck cancer. Microcirculation 7: 405-410, 2000.

102. World Health Organization: WHO Handbook for reporting results of cancer treatment. World Health Organization, Geneva, 1979.

103. Salesiotis A, Soong R, Diasio RB, Frost A and Cullen KJ: Capecitabine induces rapid, sustained response in two patients with extensive oral verrucous carcinoma. Clin Cancer Res 9: 580-585, 2003.

104. Wu CF, Chen CM, Shen YS, Huang IY, Chen CH, Chen CY, Shieh TY and Sheen MC: Effective eradication of oral verrucous carcinoma with continuous intraarterial infusion chemotherapy. Head Neck 30: 611-617, 2008.

105. Sheen MC, Sheu HM, Lai FJ, Lin SD, Wu CF, Wang YW and Lan CC: A huge verrucous carcinoma of the lower lip treated with intra-arterial infusion of methotrexate. Br J Dermatol 151: 727-729, 2004

106. Strojan P, Soba E, Budihna M and Auersperg M: Radiochemotherapy with Vinblastine, Methotrexate, and Bleomycin in the treatment of verrucous carcinoma of the head and neck. J Surg Oncol 92: 278-283, 2005

107. Yoshimura Y, Mishima K, Obara S, Nariai Y, Yoshimura H and Mikami T: Treatment modalities for oral verrucous carcinomas and their outcomes: Contribution of radiotherapy and chemotherapy. Int J Clin Oncol 6: 192-200, 2001.

108. Ogawa A, Fukuta Y, Nakajima T, Kanno SM, Obara A, Nakamura K, Mizuki H, Takeda Y and Satoh M: Treatment results of oral verrucous carcinoma and its biological behavior. Oral Oncol 40: 793-797, 2004.

109. Kawczyk-Krupka A, Waśkowska J, Raczkowska-Siostrzonek A, Kościarz-Grzesiok A, Kwiatek S, Straszak D, Latos W, Koszowski R and Sieroń A: Comparison of cryotherapy and photodynamic therapy in treatment of oral leukoplakia. Photodiagn Photodyn Ther 9: 148-155, 2012.

110. Yu CH, Lin HP, Cheng SJ, Sun A and Chen HM: Cryotherapy for oral precancers and cancers. J Formos Med Assoc 113: 272-277, 2014.

111. Lin HP, Chen HM, Cheng SJ, Yu CH and Chiang CP: Cryogun cryotherapy for oral leukoplakia. Head Neck 34: 1306-1311, 2012.

112. Yeh CJ: Treatment of verrucous hyperplasia and verrucous carcinoma by shave excision and simple cryosurgery. Int J Oral Maxillofac Surg 32: 280-283, 2003.

113. Kennedy JC, Pottier RH and Pross DC: Photodynamic therapy with endogenous protoporphyrin IX: Basic principles and present clinical experience. J Photochem Photobiol B 6: 143-148, 1990.

114. Lin HP, Chen HM, Yu CH, Yang H, Wang YP and Chiang CP: Topical photodynamic therapy is very effective for oral verrucous hyperplasia and oral erythroleukoplakia. J Oral Pathol Med 39: 624-630, 2010

115. Chen HM, Chen CT, Yang H, Lee MI, Kuo MYP, Kuo YS, Wang YP, Tsai T and Chiang CP: Successful treatment of an extensive verrucous carcinoma with topical 5-aminolevulinic acid-mediated photodynamic therapy. J Oral Pathol Med 34: 253-256, 2005. 
116. Galimberti D, Galimberti G, Pontón Montaño A, Jácome LR and Galimberti R: Oral verrucous carcinoma treated with carbon dioxide laser. J Eur Acad Dermatol Venereol 24: 976-977, 2010.

117. Azevedo LH, Galletta VC, de Paula Eduardo C, de Sousa SO and Migliari DA: Treatment of oral verrucous carcinoma with carbon dioxide laser. J Oral Maxillofac Surg 65: 2361-2366, 2007.

118. van Houten VM, Leemans CR, Kummer JA, Dijkstra J, Kuik DJ, van den Brekel MW, Snow GB and Brakenhoff RH: Molecular diagnosis of surgical margins and local recurrence in head and neck cancer patients: A prospective study. Clin Cancer Res 10 3614-3620, 2004

119. Patton LL, Epstein JB and Kerr AR: Adjunctive techniques for oral cancer examination and lesion diagnosis: A systematic review of the literature. J Am Dent Assoc 139: 896-905, 2008.

120. Lingen MW, Kalmar JR, Karrison T and Speight PM: Critical evaluation of diagnostic aids for the detection of oral cancer. Oral Oncol 44: 10-22, 2008.

121. Carlile J, Harada K, Baillie R, Macluskey M, Chisholm DM, Ogden GR, Schor SL and Schor AM: Vascular endothelial growth factor (VEGF) expression in oral tissues: Possible relevance to angiogenesis, tumour progression and field cancerisation. J Oral Pathol Med 30: 449-457, 2001.
122. Tae K, El-Naggar AK, Yoo E, Feng L, Lee JJ, Hong WK, Hittelman WN and Shin DM: Expression of vascular endothelial growth factor and microvessel density in head and neck tumorigenesis. Clin Cancer Res 6: 2821-2828, 2000.

123. Gleich LL, Zimmerman N, Wang YO and Gluckman JL: Angiogenic inhibition for the treatment of head and neck cancer. Anticancer Res 18: 2607-2609, 1998.

124. Peng Q, Tang Z, Liu O and Peng Z: Rapid prototyping-assisted maxillofacial reconstruction. Ann Med 47: 186-208, 2015.

125. Saunders RE and Derby B: Inkjet printing biomaterials for tissue engineering: Bioprinting. Int Mater Rev 59: 430-448, 2014.

126. Maire E and Withers PJ: Quantitative X-ray tomography. Int Mater Rev 59: 1-43, 2014.

127. Germershaus O, Lühmann T, Rybak J-C, Ritzer J and Meinel L: Application of natural and semi-synthetic polymers for the delivery of sensitive drugs. Int Mater Rev 60: 101-131, 2015.

128. Konopka $\mathrm{K}$ and Goslinski T: Photodynamic therapy in dentistry. J Dent Res 86: 694-707, 2007.

129. Xi S and Grandis JR: Gene therapy for the treatment of oral squamous cell carcinoma. J Dent Res 82: 11-16, 2003.

130. Rao RS, Patil S, Ghosh S and Kumari K: Current aspects and future strategies in oral cancer research: A review. J Med Radiol Pathol Surg 1: 8-13, 2015. 